sciendo

DOI. 10.2478/anpm-2019-0004

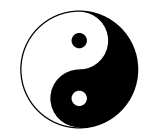

\title{
MEANS OF TRANSPORT BY UDEHE: THE TRANSFORMATION AND SURVIVAL OF MATERIAL CULTURE
}

\author{
Vladimir Degtiar ${ }^{1}$
}

\begin{abstract}
The purpose of this paper is to describe how the material culture of the indigenous hunters and fishermen of the Udehe in the Far East of Russia have been transformed by outside influence, from an autonomous and already sophisticated culture to a dependent and modernized one. The discussion centres around the means of water transport, two kinds of dugout boats (the bat and omorochka) because they were and still are essential for hunting and fishing, which are the main economic activities of Udehe. The author demonstrates how this one part of material culture has changed in manufacturing and use, and what has changed in the everyday life due to this transformation.
\end{abstract}

KEY WORDS: Udehe - dugout boat - Russian Far East - modernization - material culture - transformation

\section{Introduction}

The influence of other cultures on the Udehe and their ancestors has occurred over many centuries; because of their socio-economic, historical and ethno-cultural relations with neighbouring nations, ethnogenetic and assimilation processes have taken place (Startsev 2017: 5). Through the trade of fur and other hunting products, the Udehe received such material goods as silk and cotton clothes, firearms, metal products, glass beads, earthenware and porcelain, crops, liquor and other goods which they themselves were unable to produce. A sophistication of their culture took place, but it could still

1 Contact: Vladimir Degtiar, Department of AsianStudies, Faculty of Arts, Palacký University Olomouc; e-mail: v.degtar@gmail.com. The work was supported from European Regional Development FundProject "Sinophone Borderlands - Interaction at the Edges" CZ.02. 1.01/0.0/0.0/16_019/0000 791. Special thanks to my colleges Oksana Zvidennaya (research fellow of the Institute of Ethnology and Anthropology of the Russian Academy of Sciences, Moscow) and Dr. A. Startsev (chief researcher of Institute of Ethnography of the Peoples of the Far-East, Vladivostok) who supported me during the writing of this article and to all the informants without whom this article would not have been possible.

This work is licensed under the Creative Commons Attribution-Noncommercial-No Devivs 3.0 License 
exist autonomously at the expense of the traditional life-support system, using their own weapons and means of transport. However, the Udehe and other indigenous peoples of this region were the main actors in the history of Northeast Asia until the 1860s, when the Russian Empire acquired the territories of the present Khabarovsk and Primorsky Krai (Sasaki 2010: 185-186). Since the 1930s, a de-localization processes began to occur in various aspects of the material and spiritual culture of the Udehe people. A transition from being a traditional-independent to a modernized-dependent culture began. In this context, de-localization means that part of the traditional economy is no longer locally produced but completely dependent on the outside; this can be seen, for example, in commercially-sourced energy sources (Pelto 1973: 165; Sasaki 2010: 180).

Coercive measures taken by the Soviet authorities to include the aboriginal population in Soviet society led to the rapid and serious transformation of the material and spiritual culture of the Udehe people. Shiro Sasaki writes that the modernization process reached the point of no return in the 1960s, in the transition from 'traditional' to 'modernized' culture, one of the main reasons being the motorized equipment: "However, insofar as motor vehicles and high-performance firearms were still not introduced, the techniques, distance to animals, and social rules and ethics were not seriously affected" (Sasaki 2010: 187).

This article will describe this transformational process illustrated by the example of means of water transport of the Udehe. Consideration will be given to the construction and use of traditional boats - bat and omorochka. The transformation of these boats as well as the consequences of this transformation for the Udehe will comprise the main part of this article.

\section{Methodology}

In addition to literary sources, this study draws on material which the author was able to collect during his visit to the most important settlements of the Udehe in Khabarovsk and Primorsky Krai of Far East of Russia in November of 2018 and in April of 2019: Bikin (Krasny Yar), Iman (Krutoy Yar), Khor (Gvasyugi), Anyuy (Arsen'yevo, Uni). This includes interviews with colleagues and experts on the Udehe. In addition to the various interview techniques, a historical comparative method was used.

\section{Udehe and the Importance of Shipping}

The Udehe are traditionally hunters, gatherers and fishermen. The Udehe (or Udege, Udeghe) language is more closely related to Oroch and belongs to the Udegheic branch of Tungusic languages (Janhunen 2012; Hölzl 2018). The ethnonym Udehe can be translated as "forest people", or better "people who live in a deep forest". Until the forced collectivization in the 1930s by the Soviet state, they inhabited small encampments dispersed along the forested banks of the tributaries of the Ussuri or Amur rivers and other rivers flowing into the Sea of Japan on both sides of the main ridge of the SikhoteAlin mountain range. Today they occupy lands in Russia's Primorsky Krai as well as in the southern sections of Khabarovsk Krai (Sasaki 2010: 257) (Fig.1). According to the 2010 census there are 1.413 Udehe people living in a few ethnic villages. ${ }^{2}$

2 Retrieved May 07, 2019, from [http://www.gks.ru/free_doc/new_site/perepis2010/croc/ Documents/Vol4/pub-0401.pdf]. 


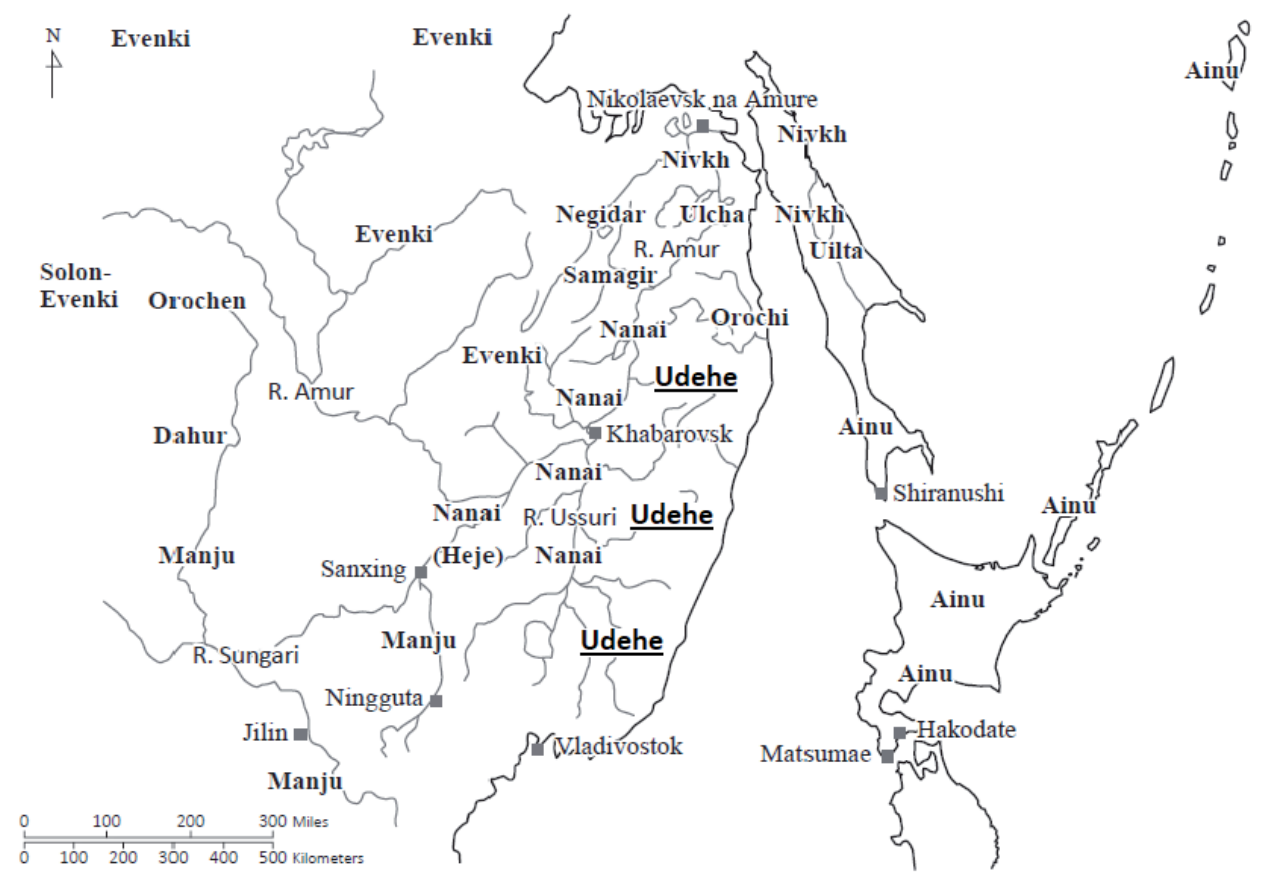

Fig 1. Indigenous People of the Russian Far East and Northern China (Sasaki 2016: 161).

The traditional economic activity of the Udehe is complex and based on a seasonal combination of hunting, fishing and gathering, and demanded great mobility. Before the arrival of Chinese and Russian settlers (along with farming and a sedentary way of life), the Udehe people were nomadic up to the mid- $19^{\text {th }}$ century. At the same time, the rivers played a very important role in the life of the Udehe people: as transport routes and as a source of food. The Udehe (and Orochi) used boats typical for the peoples of the Amur basin, of which there are two different kinds: the bat (udeg.: ana), used for transportation and moving from one camp to another; and the omorochka (udeg.: utungiä, utung̈̈, ugda), used mainly for hunting (Fig. 2) (Atlas Sibiri 1961: 112).

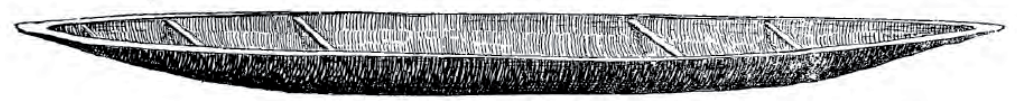

a

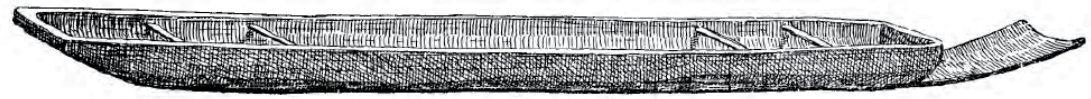

b

Fig 2. a - omorochka, b - bat (Atlas Sibiri 1961: 126). 
To understand the role of water vehicles for the Udehe people, it is necessary to consider the specifics of their resettlement and movement throughout the year. During the time when rivers freeze, from late autumn to early spring, the Udehe hunted animals (especially fur animals, for trade) and lived in permanent dwellings in places where they could secure protection from the wind, with a source of drinking water, and in proximity to a fishing area. In summer, however, the Udehe lived in temporary shelters on the banks of the rivers or nearby with convenient access to the shore (Przhevalskiy 1949: 113; Larkin 1959: 14; Startsev 1996: 17). Most likely, summer settlements were not far away from the winter ones; here, the presence of fish (and spawning grounds) played a decisive role, as well as game animals, and wind (which would influence the presence of mosquitos). It must be taken into account that travelling in boats against the current, especially in the upper reaches of rivers such as the Iman, Bikin and Khor, was a very energy-intensive matter, often associated with the danger of capsizing, and required great skill. One famous researcher of the Udehe, Vladimir K. Arsenyev, writes that to paddle against the current, an Udehe traveller needs almost ten days to get to the watershed Sikhote-Alin, and one and a half to two days for the same distance in the direction of the current back. Arsenyev also wrote that Chinese ginseng seekers, merchants and Russian expeditions always hired an aboriginal to cross these rivers (Arsenjev 1914/2012: 353). The Udehe underwent long trips only in rare cases, going down to the Ussuri river basin, especially for the purpose of trading.

The current in the high reaches was much faster than in the lower ones, the permeability was much worse because of windbreaks, and the Udehe groups in the $19^{\text {th }}$ century settled along these rivers in the middle and upper reaches (Larkin 1958: 8; Shestakov 1891/2010: 37). Therefore, the choice of locations for summer homes was made in such a way as to minimize distant trips along the rivers. As a result, there was a permanent migration between spring-summer (temporary) and autumn-winter (permanent) places of residence. Sasaki writes on this occasion that "transportation equipment often restricted hunters' locations" and accordingly fishing and gathering (Sasaki 2010: 182).

Thus, with the advent of the motorboat, the need for such migration would become relative and the Udehe could concentrate on a permanent home, and in the summertime just go fishing and hunting by boat for a short time, as it is today. The collectivization and the transition to a sedentary lifestyle, occurred before the appearance and widespread use of motorboats. The modernization (motorboats) was a consequence of the collectivization process, not a cause of it (see Chapter 4).

\section{The Construction and Transformation of bat}

Large dugout boats (bats) could be found mainly on fast mountain rivers and rapids, the surface of which is often littered with windbreaks that were typical for the Udehe's living environment (Chepelev 2004: 141). "Only long and narrow bats that had thick sides and bottoms, managed by experienced people, could travel on such rivers" (Lopatin 1922: 126). The bat, as well as the omorochka, were made in a place and time when a need for one appeared. For example, when a river was reached passing through the Sikhote-Alin, then the main task was to find a suitable tree (Arsenyev 2012: 353).

The dugout bat is made of a thick poplar which has reached an age of 250-300 years. Usually, the thickness of the tree is determined by the eye or the distance from the 
elbow of the arm bent to the chest to the tips of the fingers extended to the side of the other arm (Startsev 1996: 128). Selected tree trunks are hollowed out with special tools (Fig. 3). A distinctive feature of the bat is its spatulate nose, which was needed in order not to cut the water, but to climb it, and thanks to this even the most dangerous rapids could be passed (Startsev 1996: 131, as cited in Arsenyev-Titov 1928: 83).

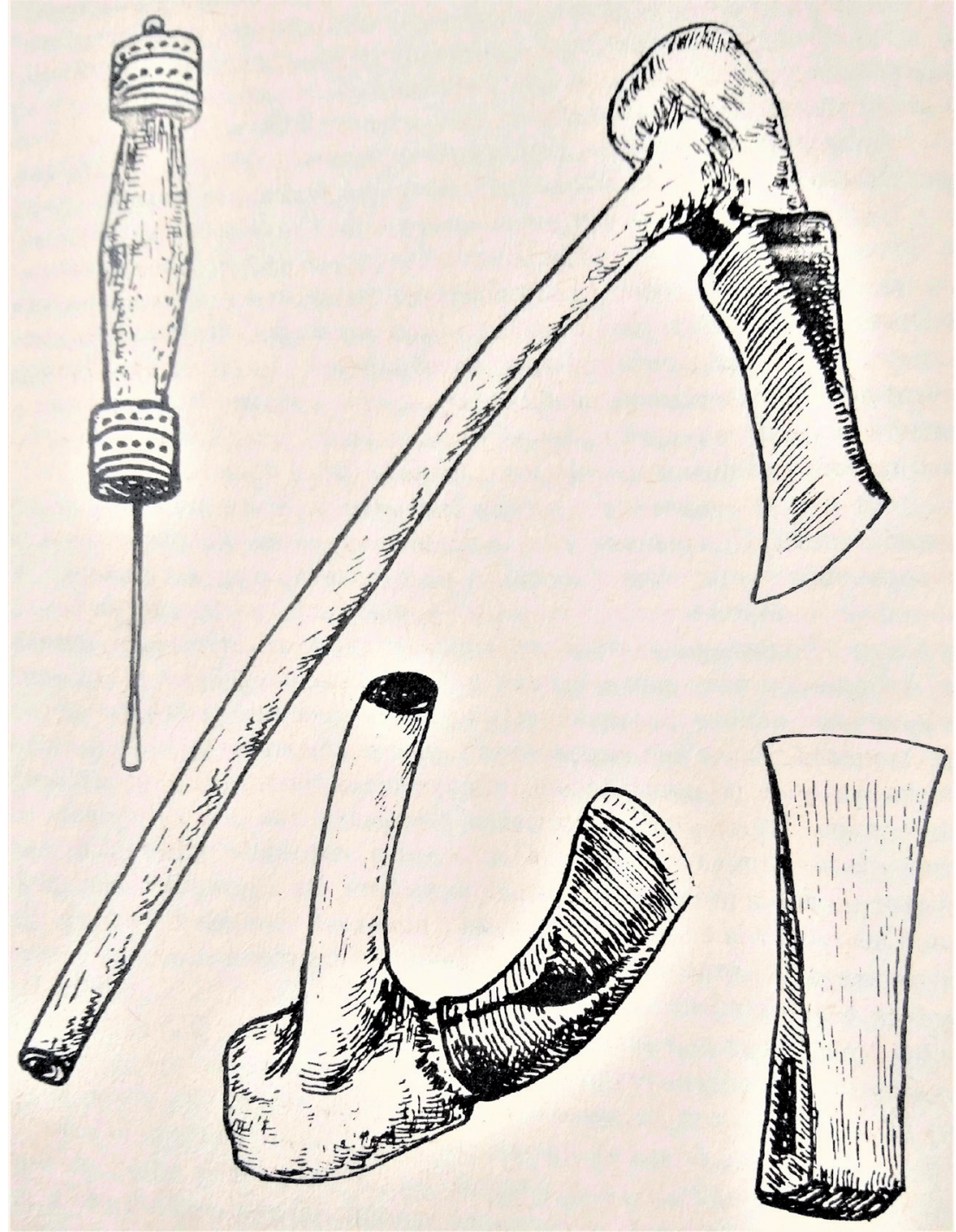

Fig 3. Tools for making dugout boats (drawing: Startsev 1996: 130).

In the final phase of construction, the bat is burned over the fire. This was done in order to bend the sides shaping the boat outward and dry the tree and pitch in the bark with smoke (Startsev 1996: 131). The size of a bat varied and often depended on the size of the timber of the tree from which it was made. On average, the length of a big bat was up to seven meters, the length of the nose was one and a half meters, the width of the 
boat was one meter, and the width and height of the sides from 50 to 60 centimetres, the thickness of side walls being two to three centimetres. The load capacity of such a boat reaches one ton (Startsev 1996: 131, as cited in Larkin 1959: 147-148) (Fig. 4).

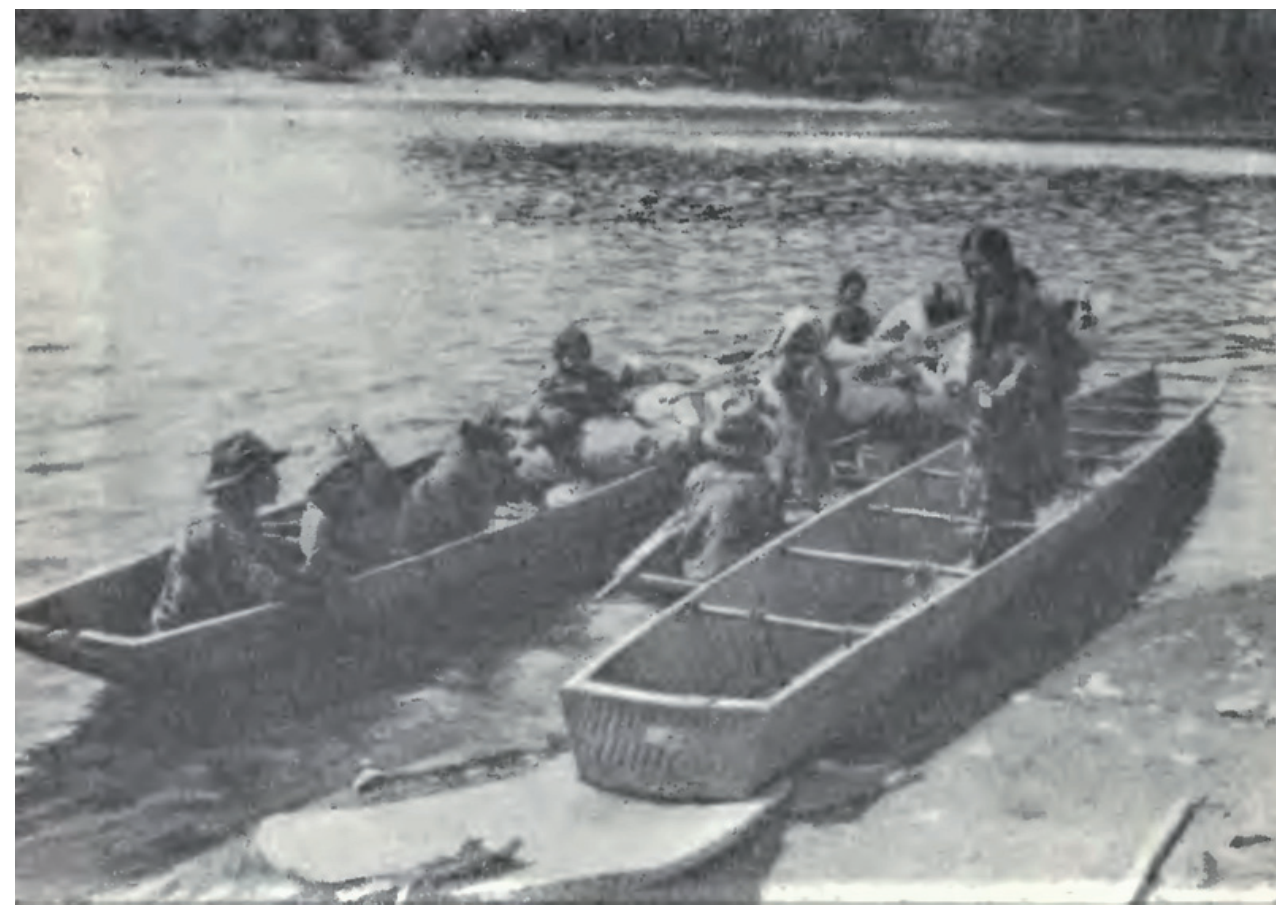

Fig 4. An Udehe family moves to a new place of residence (Narody Sibiri 1956: 834).

Bats are moved with the help of poles and paddles, which are used depending on the situation. When they travel up-river, they propel themselves with poles, while when they travel down the river, paddles are rowed at the stern, and the person at the bow navigates the boat by pole (Startsev 1996: 132). A bat is usually rowed by two people (Arsenyev 1926: 22) (Fig. 5). Earlier, while travelling up the river, several dogs were harnessed to help pull the boat (Venyukov 1970: 127).
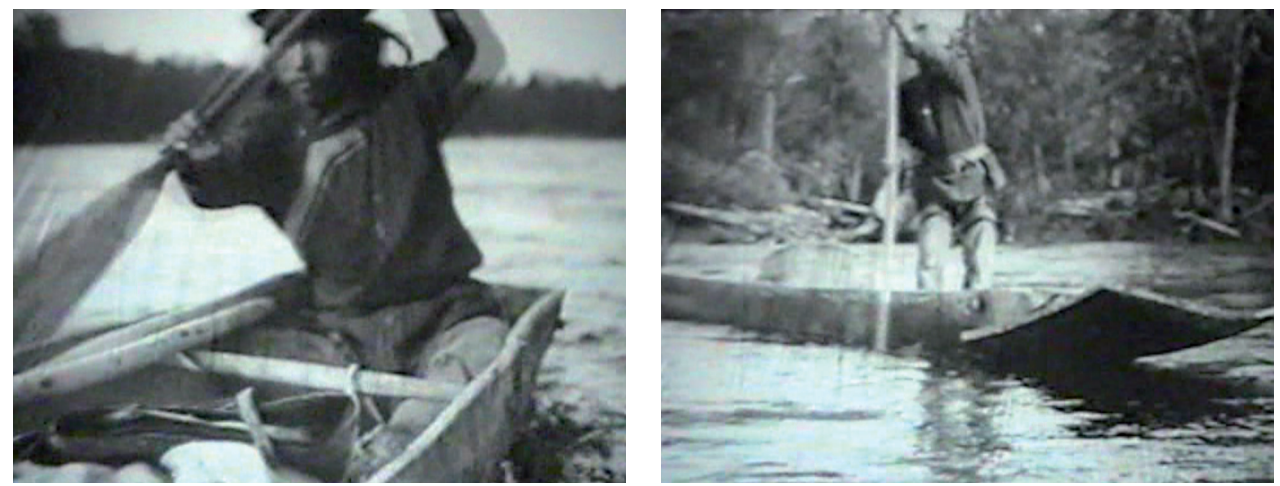

Fig 5. "Forest people", film by Alexander Litvinov, Sovkino, Moscow, 1929, 4:32 min. 


\subsection{The Transformation of the $b a t^{3}$}

The traditional bat was widely used until the mid-1950s. Then it was replaced by a composite boat and no longer hollowed out of a tree trunk $k^{4}$. Composite boats were unknown to the Udehe in the past and were widely distributed in the $19^{\text {th }}$ century among the Nanai, Ulch, Nivkh, Oroch, Negidal, Amur Evenki (Shrenk 1899: 200) (Fig. 6).

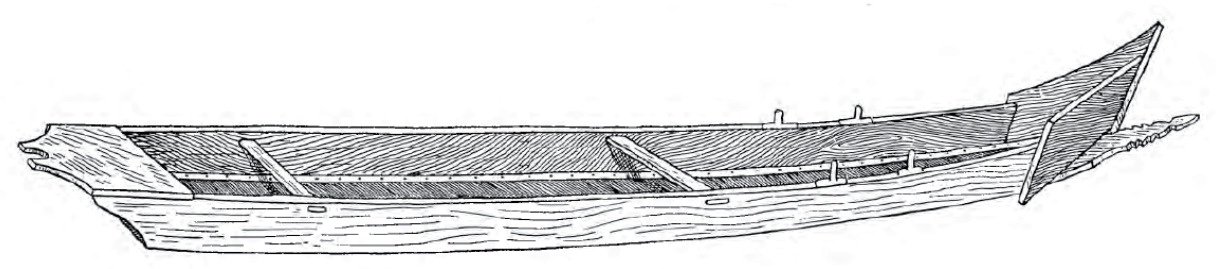

Fig 6. A composite boat (Atlas Sibiri 1961: 127).

As in the manufacture of the traditional bat, construction began with the search for a suitable tree for the boat. Also today, it depends on the characteristics of the tree trunk. Nowadays, the log is not hollowed out, but cut into boards. The new bat ${ }^{5}$ is not made in forest directly near the place of its intended use anymore, but in the village, from boards, with the help of modern tools (for example, a plane, machine for making boards, etc.). According to one informant, the species of wood has also changed: now cedar (lat. Cedrus) and linden are being used more, since the production of boards from such wood species was better than from poplar. However, poplar is also still used for composite boats. ${ }^{6}$ The boat is made up of five boards: three boards make the bottom and one board on each side. Additionally, another five to six small boards for lintels, seats and the bow of the boat are needed (Fig 8). ${ }^{7}$

By the 1950s, almost every family had a Soviet-made boat engine made by the brand "Moskva" or "Vikhr"8 (Startsev 1996: 136). At the same time, the motors were first placed on dugout bats, which required a small reworking of the rear of the boat: the back of the boat was cut off and a thick board was attached in its place (Fig 7). ${ }^{9}$ In the words of the informant, the new bat began to be built from the bottom up. The bottom is adjusted to one diameter, a groove hollowed out, and the angle of the middle sides are adjusted for the flow of the boat. Then the frames (or straps, rus. шпангоуты), made of wood, are inserted (5-6) to hold the sides. The seats are attached to them in the end. ${ }^{10}$

3 The transformation and modernization of the material culture of the Udehe people, and in particular of bat, is vividly visible in the comparison of two documentaries: "Forest People" (1929; see Fig. 5) and "Mayak from the Bikin river" (1958; rus.: “Маяка с реки Бекин», Центрнаучфильм (ЦНФ), directed by Ю.Файт).

4 Today's bat consists of 5 boards (Kyalundziga Grigory, the boatbuilder from Krasny Yar, February 2019).

5 Not everyone now uses the name bat. In the village of Gvasyugi e.g., in comparison to the village of Krasny Yar, almost everyone says just a boat.

6 Interview with Alexandr Eremeev (Krasny Yar, January 2018).

7 Ibid.

8 Eng.: whirlwind.

9 Interview with Alexandr Eremeev (Krasny Yar, January 2018).

${ }^{10}$ Ibid. 


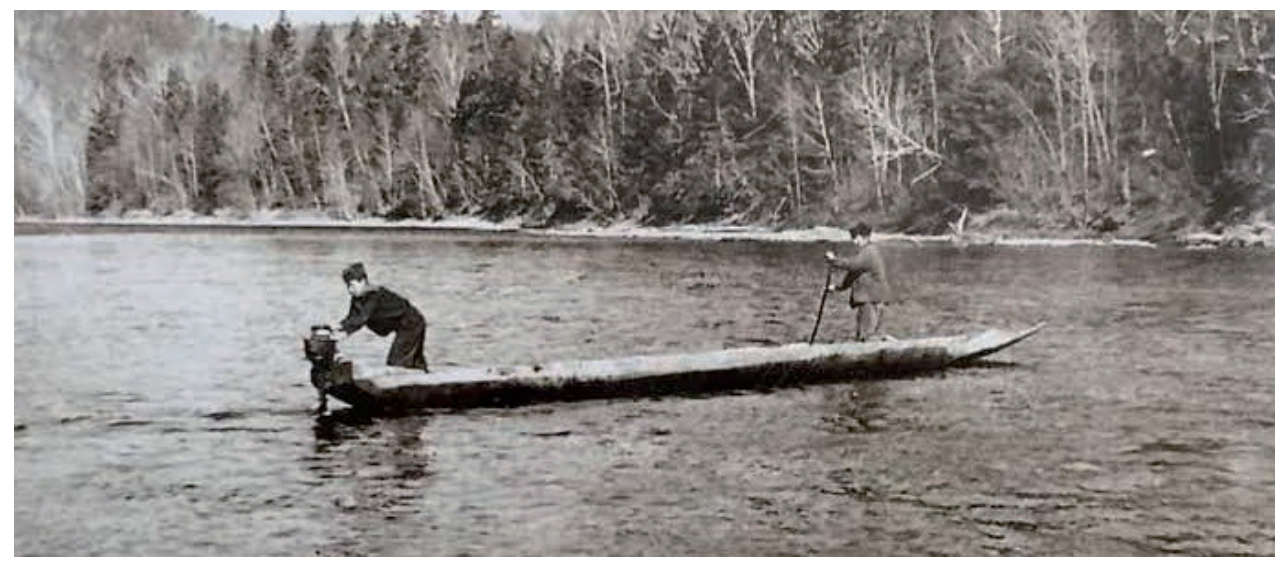

Fig 7. A dugout boat with an outboard motor (from Kyalundzyuga - Kimonko 2016: 34).

Later, a transom was built, first on dugout boats then on the composite boats. For a "Vikhr" brand motor, the height of this kind of a transom should be about $39 \mathrm{~cm}$ and for one of the new, non-Russian motors today, $42-43 \mathrm{~cm}$ in height. The bottom of the dugout bat had a thickness of about $6 \mathrm{~cm}$; with a composite boat made of planks, the thickness of the board or bottom is a maximum of $3 \mathrm{~cm}$. Therefore, it can be bent from the front and rear to the top.

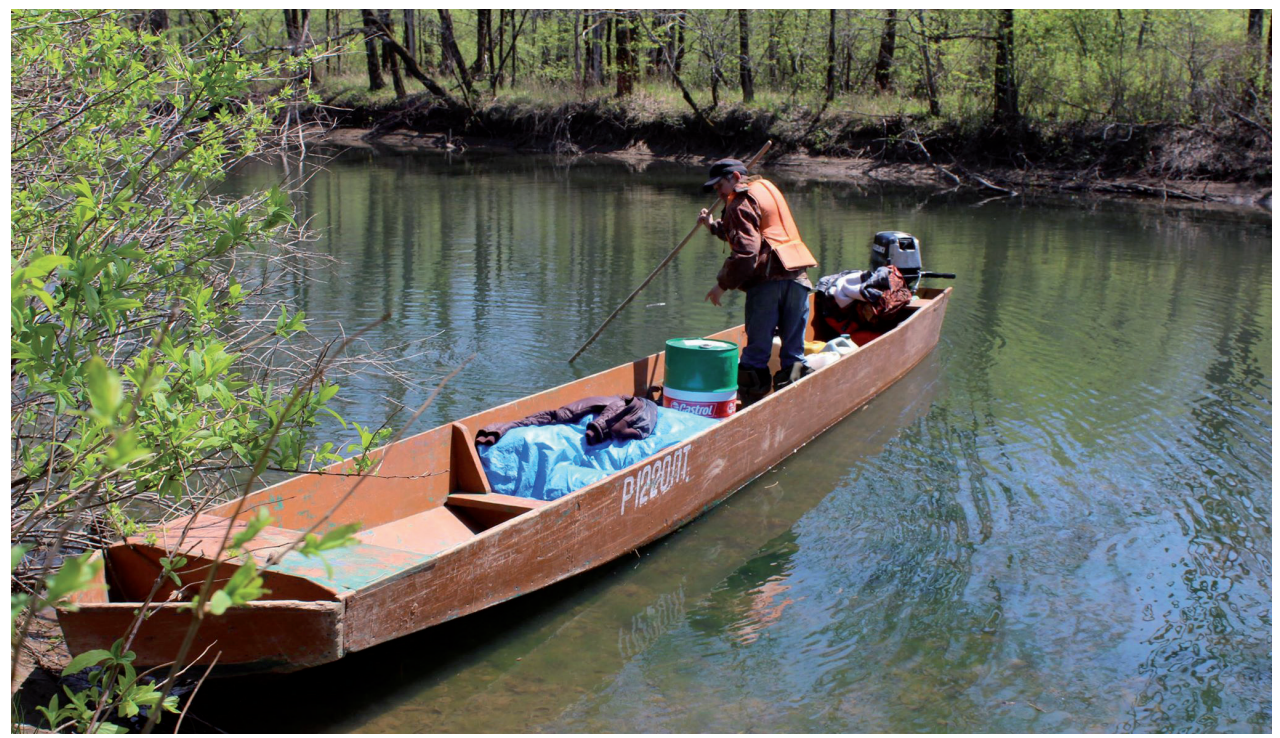

Fig 8. A modern bat (Photo: Oksana Zvidennaya, 2010).

With the advent of the engine, travel speeds increased, and the spade nose began to drill into the water, instead of climbing over it. That's why the nose of the modern bat became pointed, which also made the entire construction process easier. The nose is made separately from shorter boards today. ${ }^{11}$

11 Interview with Alexandr Eremeev (Krasny Yar, January 2018). 
In form, the new bat almost copies its dugout predecessor, which indicates that the shape of the boat is the most suitable for local rivers: "[...] it is better to sail on such a boat along our rivers; try to transport cargo on the state boat on shallows - you will break the engine ten times $[\ldots]^{\prime \prime} .{ }^{12}$

The method of steering the bat changed as well. A man standing or sitting in the back with a pole or a paddle now only needs to sit and control the motor. The man who is ahead, like in old times, should know how to navigate the river well. Moving his right or left hand signals to the "motor man" where to turn the boat. When the boat gets to a shallow place everyone in the boat pushes it out with poles into the deeper water (Startsev 1996: 136).

\section{The Construction and Transformation of the omorochka}

In contrast to the multi-seat bat, omorochka was most often smaller and made by one person, less often by two people. The process of making dugout omorochka is almost identical to the construction of a dugout bat, only there are several differences in terms of composition.

The bottom of the omorochka is flat and oval, so as not to produce waves which could scare prey animals. The nose and the tail end are pointed. Its length ranges from five to six meters, the width of the sides measuring $60 \mathrm{~cm}$, the height from the bottom to the edge of the sides is about $25 \mathrm{~cm}$, the thickness of the sides is about two centimetres. Omorochkas are made from poplar or linden (Startsev 1996: 132; Kyalundziga ${ }^{13}$ ). In contrast to the bat, one person could manoeuvre the boat and move it where they want to go. According to the informant, in order to give shape to the sides of the boat, the boat was filled with water or boiling water, and it is not necessary to fire-harden it. $^{14}$

The omorochka was constantly used for different needs (to go for berry picking, bring home game), but its main purpose was to hunt and fish with a spear at night (Startsev 1996: 133). For night hunting, the Udehe took special short paddles, 50-60 cm in length.

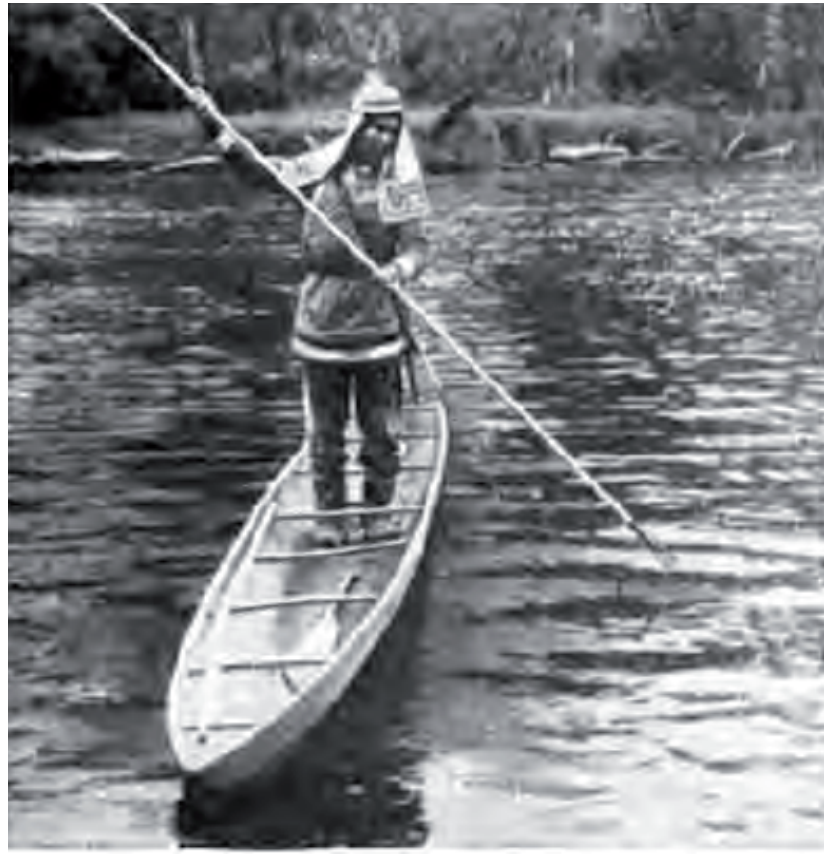

Fig. 9 An Udehe man hunting on an omorochka (Atlas Sibiri 1956:124).

\footnotetext{
12 Ibid.

13 A boat builder from Verkhniy Pereval village, Bikin River.

${ }^{14}$ Interview with Alexandr Eremeev (Krasny Yar, January 2018).
} 
"The small size of the paddles allows them to avoid unnecessary noise and splashing, which makes it possible to paddle unnoticed to the watering animal [...] In addition to paddles and long poles, each omorochka has a pair of poles which are used during hunting in shallow and quiet backwaters [...] the hunter paddles close to the animal for a short distance, he sticks poles into the bottom of the canal and shoots" (Startsev 1996:133) (Fig. 9).

Navigating the omorochka requires a great deal of skill: "For a person unfamiliar with the omorochka, operating it even in a sitting position is very difficult, as it is very light weight and the slightest careless or awkward movement leads to the fact that the rim rolls over, and an inexperienced swimmer sitting in it falls into the water; each Orochen ${ }^{15}$ boats completely free on an omorochka standing, feeling at home in it and often only with quick turns of his hull he forces his light vessel to turn round and sideways" (Belkovich 1895: 29). Arsenyev wrote also: "It is not enough to make a ulimagda (omorochka), one must be able to manoeuvre it, one must adapt to the rivers, study their properties. Unfortunately, this is granted only by many years of experience" (Arsenyev 2012:353). As the informant says, "if the head's workings are normal, then you can quickly learn."16

\subsection{The Transformation of the omorochka}

In the case of the omorochka almost nothing has changed in its form and its use (Fig 10.). It remains a dugout boat. Only the method of its manufacture and transportation to the river have changed. Now, a petrol or electric saw and a plane are used for the main work, which makes the manufacturing process easier and faster.

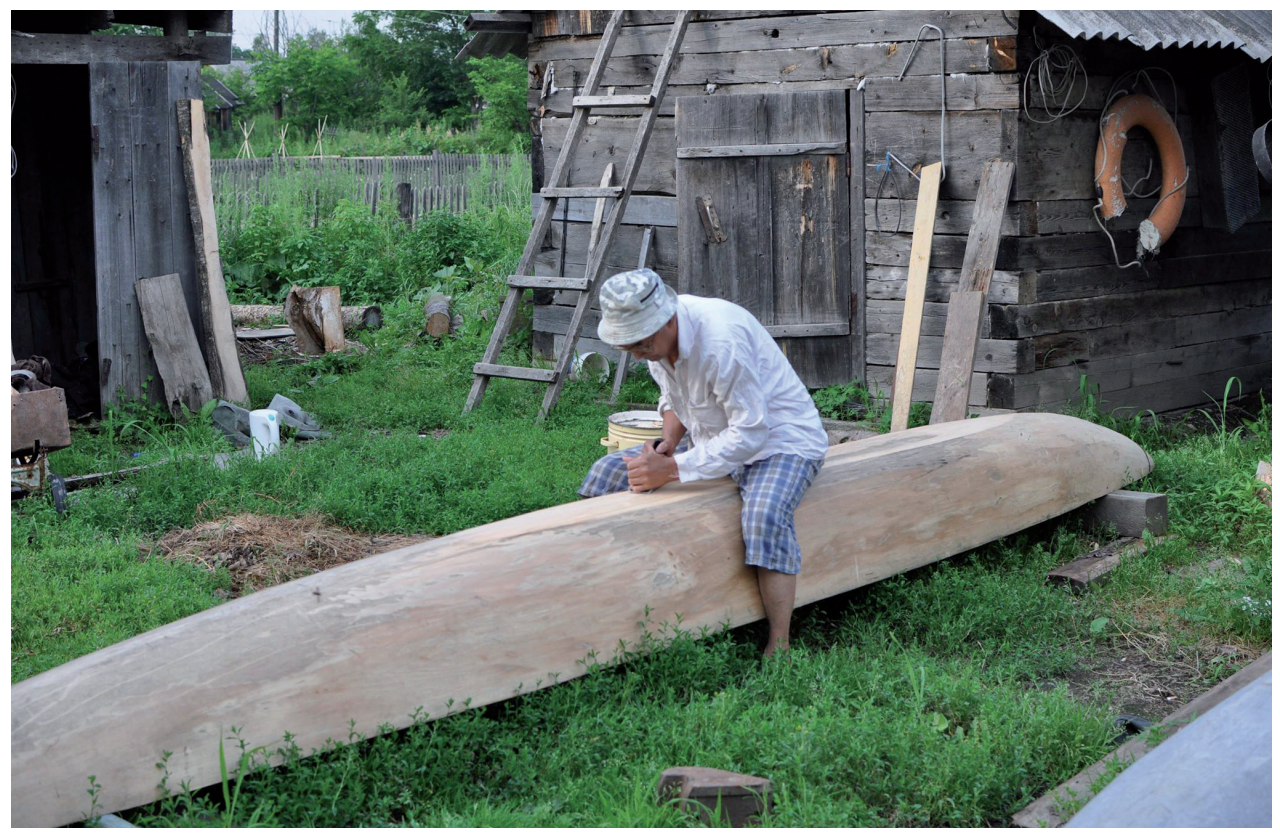

Fig 10. Manufactoring of omorochka's bottom with plane (Photo: Oksana Zvidennaya, Krasny Yar, 2010).

${ }^{15}$ By the end of the $19^{\text {th }}$ century, the Orochen and Udehe had been mistaken for the same ethnic group.

${ }^{16}$ Interview with Alexandr Eremeev (Krasny Yar, January 2018). 
However, if we consider that before it is complete the boat was first soaked in water for about a year, then this is relative. ${ }^{17}$ Traditional tools like an axe or adzes are still used for small tasks.

The transport to hunting grounds is now done by putting a omorochka on the bat with a motor or transporting it by car if there are roads which lead to the rivers. But, hunting by night on an omorochka has barely changed.

\section{Discussion on the Transformation of Boats and the Impact on the Everyday Life of the Udehe}

It is obvious that the emergence of motor boats for the aboriginal people living in the taiga zone, where rivers are one of the main transport routes, has influenced their life. But, it would be false to consider this phenomenon as sudden and separate from the other processes of transformation in their society which began in the late $19^{\text {th }}-$ early $20^{\text {th }}$ century. Two processes - the entry of motorized boats into widespread use and the completion of collectivization in the 1950s - were a parallel occurrence. Sasaki writes: "It would have been impossible to integrate the people and their productive organisation into one village and one farm if they had had only traditional transportation equipment such as dugout boats, birch-bark canoes, dog-sleds and skis" (Sasaki 2010: 189). It is worth explaining that since the 1930s hunting equipment, foodstuffs, and finally outboard motors were supplied by the Soviet state to places where a higher density of the Udehe people resided (Startsev 1996: 122-123). Motorized vehicles were initially used by the state to support new Russian-type settlements of Udehe. So, for example on the Khor River there was a hydroplane boat which delivered the necessary goods to the Udehe; at Krasny Yar, the largest Udehe village today, it was delivered by aviation (through the airfield in Olon). Motorized water vehicles were already present in the everyday life of Udehe, but were not yet included in private widespread use.

From the interview with Startsev, who studied the Udehe people for more than 40 years, starting in the 1960s, the process of motorboats entering into the life of the Udehe was slow: "at first they saw motor vehicles from workers of Integralsojuz ${ }^{18}$ (traders and organizers). The Udehe rode with pleasure on such boats. Then motor boats appeared in collective farms and so it continued until the 1960s. During this time, every Udehe already knew what a motorboat was and wanted to buy one. An Udehe built the boat himself, but he bought the outboard motor."19 The process of adopting such a novelty was, on the one hand, complicated by the technical and economical components: the reworking of the old bat design to accommodate the motor, buying the motor and fuel, mastering the new driving technique; but on the other hand, this process was accelerated by the fact that for an Udehe, the motor crucially facilitated one of the most important daily activities - movement along the river. We can contrast this with, for example, the attempts of the Soviet authorities to impose farming on the Udehe, which almost disappeared by the end of the 1950s, as it distracted from the main activity: hunting (Startsev 2014: 26). Anything that could facilitate traditional practices such as high performance firearms, snowmobiles, and motorboats was welcomed and quickly mastered (Sasaki 2010: 187). Now, for example, with a Vikhr

\footnotetext{
${ }^{17}$ Interview with Kyalundziga Grigory (Krasny Yar, February 2019).

${ }^{18}$ Integral union, later Kolkhoz.

${ }^{19}$ Interview with Startsev A.F., May 2019.
} 
motor it was possible to travel in one day from the village of Krasny Yar to Ulunga (200 $\mathrm{km}$ ), which previously took more than a week. Not only did the speed of movement change here, but also the application of physical effort; the pushing of two or more people against the current with poles has now been replaced by one man "sitting on the motor". For the first time, it also became possible for children to carry a heavy transport boat, whereas in the past only adult men and women did it (Startsev 1996: 136). However, the complexity and danger of passing through the middle and upper parts of the rivers has not decreased due to this and still requires great skills. ${ }^{20}$

But, the most important thing was the process of including the remote hunting grounds, where previously no humans had set foot and the animal population remained massive. This allowed hunters to increase the acquisition of fur animals by two to three times. ${ }^{21}$ Thus, the process of hunting rehabilitation began to occur, which compensated for past migration trends, by increasing mobility through motorized vehicles. ${ }^{22}$ For example, the probability to shoot, by chance, an animal from the boat became higher, as it became more common to travel long distances, which also increased the acquisition. On the other hand, animals began to associate the noise of the motor with danger, since the hunters began to shoot from the boat immediately upon sighting an animal. Another effect of the motorboat, according to the informant, was the erosion of the shore and thus a change in the river bed..$^{23}$ This means, that motorboats have influenced not only humans, but also animals and rivers.

Before car transport became more accessible and roads improved in the 1980s, the Udehe travelled to neighbouring Udehe and Russian villages along the banks of the river (Startsev 1996: 136). An increase in mobility increased social activity. Nowadays, a motor bat is used mainly for hunting, fishing and taking tourists to the upper reaches of rivers, while other Udehe settlements are visited by car.

The construction of a bat to accommodate a motor, as well as the purchase of a motor, fell almost completely on the shoulders of the Udehe after the collapse of the Soviet Union. For example, one of the main problems today is the extraction of suitable wood for boards (timber removal from the forest) or the purchase of ready-made boards at the sawmill, which was done by Selsoviet (rural council), during the Soviet Union. ${ }^{24}$

We can also call it the "motorboat revolution", if one uses the terminology of Pertti J. Pelto (1973) and apply his "snowmobile revolution" from the Kolta Saami to the Udehe, yet with one big difference. There was no complete dependence on the new technical means. The methods of hunting as pursuit, tracking, calling, dogs, etc. are still based on walking on foot (skiing in winter).

There was a process of de-localization of water vehicles for the Udehe in the case of the bat. But the process of sociocultural differentiation, which occurred within Kolta Saami, according to Sasaki, in the socialist environment of equal access in comparison with the capitalist environment, took place at a different level (Sasaki 2010: 179-180). Today, socio-cultural differentiation in relation to motorboats is observed, for example, in the village of Krasny Yar, but as in the Soviet era, the most active and lucky hunter

${ }^{20}$ Interview with Zvidennaya O., (Wladiwostok, November 2018).

${ }^{21}$ Interview with Startsev A.F., (Wladiwostok, May 2019).

${ }^{22}$ We should not forget the appearance of snowmobiles, which has gas mileage 1.5 times less than that of motor boats.

${ }^{23}$ Interview with Kyalundziga Grigory (Krasny Yar, February 2019).

${ }^{24}$ Interview with Alexandr Eremeev (Krasny Yar, January 2018). 
also received the best equipment. In a hypothetical case, if the motorboats became inaccessible, the processes of reorganization, re-settlement, etc. would still take place, but this would not be an unsolvable problem. ${ }^{25}$

In case of the omorochka, with the advent of cars and motorboats, its function as an everyday vehicle has ended. However, unlike the bat, the omorochka is still essentially a dugout boat and no outboard motors are used. So, the main water vehicle for hunting was not subjected to de-localization.

\section{Conclusion}

Objects from the material culture that the Udehe could not produce on their own have been traded for with other ethnic groups since ancient times. At the same time, their own culture was sophisticated, but remained traditionally independent. The process of the de-localization of individual layers of their culture began relatively recently - in the 1950s. The Soviet state, seeking to control the aboriginal people and manage the supply of fur, invented collectivization and modernization. Compensating for a sedentary life through public procurement, the Udehe "regained" their past mobility through motorized vehicles. The bat, the larger of the two dugout boats of the Udehe, was remade and motorized. This allowed the inclusion of new remote hunting areas and increase production. Before the advent of roads and road transport, motorboats played an important role in socio-economic life, allowing for more frequent visits to neighbouring settlements along the river. Today, the bat is an indispensable vehicle and is used for hunting, fishing, gathering and tourism. The omorochka, the second, smaller boat, is still an important dugout boat and is used today for hunting at night. Its function as an everyday vehicle lost its meaning with the advent of the motorboat.

Using only traditional water vehicles, settling without outside support was hardly possible. But the modernization did not put the main economic activity of the Udehe people into direct dependence and also did not greatly reduce the physical and psychological distance to animals and nature.

\section{Literature:}

\section{Arsenyev V.K.}

2012 Собрание сочинений в 6 томах. Том 3. Научно-практические публикации, отчеты доклады. 1906-1916 гг., Рубеж, Владивосток. [Collected Works in 6 volumes. Volume 3. Scientific and practical publications, reports. 1906-1916, Rubezh, Vladivostok 2012]

(Original work published 1914 Китайцы в Уссурийском крае: Историко - этнографический очерк. Арсеньев В.К. Зап. Приамур. отд-ния ИРГО. Хабаровск: Т.10. Вып.1 [The Chinese in the Ussuri region: Historical - ethnographic essay. Arsenyev V.K. Zap. Priamur. otd-niya IRGO. Khabarovsk: T.10. Vyp.1];

\section{Atlas Sibiri (Атлас Сибири)}

1961 Атлас Сибири. Историко-этнографический Атлас Сибири. Москва, Ленинград: Издательство Академии Наук СССР [Atlas of Siberia. Historical and Ethnographic Atlas of Siberia. Moscow, Leningrad: Publishing House of the Academy of Sciences of the USSR];

\footnotetext{
${ }^{25}$ Interviews with Zvidennaya, Kyalundzyuga (Wladiwostok, Krasniy Yar, 2019).
} 


\section{Belkovich A.L.}

1894-1895 Из дневника члена Приамурского отдела Императорского русского географического общества А. А. Бельковича во время экспедиции по исследованию Уссурийского края летом 1894 года / А. А. Белькович, Хабаровск : Труды ПОИРГО [From the diary of a member of the Amur Department of the Imperial Russian Geographical Society A. L. Belkovich during an expedition to explore the Ussuri region in the summer of 1894 / A. L. Belkovich, Khabarovsk: Proceedings of POIRGO];

\section{Chepelev V.P.}

2004 Традиционные водные средства передвижения у коренных народов Нижнего Амура и Сахалина. Чапелев В.П. In: Изучение памятников морской археологии. Санкт-Петербург: ИИМК РАН, Вып. 5. рр. 141161 [Traditional water vehicles of the indigenous peoples of the Lower Amur and Sakhalin. Chapelev V.P. In: The study of the monuments of maritime archeology. St. Petersburg: IIMK RAS, Vol. five.];

\section{Hölzl, Andreas}

2018 Udi, Udihe and the language(s) of the Kyakala. München: International Journal of Diachronic Linguistics and Linguistic Reconstruction, Vol. 15, pp. 111-146;

\section{Janhunen, Juha}

2012 The expansion of Tungusic as an ethnic and linguistic process. In: Andrej L. Malchukov \& Lindsay J. Whaley (eds.). Recent advances in Tungusic linguistics, pp. 5-16. Wiesbaden: Harrassowitz.;

\section{Kyalundzyuga V.T., Kimonko N.E.}

2016 Мир хозяина воды Аунгиэ. Кялундзига В.Т., Кимонко Н.Е. Хабаровск [Тһе world of the master of the water Lungie. Kyalundzyuga V.T., Kimonko N.E. Khabarovsk];

\section{Larkin V.G.}

1958 Удэгейцы: (Историко этнографический очерк с середины XIX в. до наших дней). Владивосток. [Udehe: (Historically ethnographic essay from the midnineteenth century to the present day). Vladivostok.];

1959 Хозяйство и средства передвижения удэгейцев до установления советской власти. Ларькин В.Г. Саранск: Тр. ДВФСО ФН СССР им.В.А.Комарова. [The economy and vehicles of the Udege before the establishment of Soviet power. Larkin V.G. Saransk: Tr. DVFSO FN USSR them.V.L. Komarova], pp. 126-153;

\section{Narody, Sibiri}

1956 Народы Сибири. Москва, Институт Этнографии имени Миклухо-Маклая, Ленинград: Издательство Академии Наук СССР [The peoples of Siberia. Moscow, Miklouho-Maclay Institute of Ethnography, Leningrad: Publishing House of the Academy of Sciences of the USSR];

\section{Pelto, Pertti J.}

1973 The Snowmobile Revolution: Technology and Social Change in the Arctic. Menlo Park (CA): Cummings Publishing Company.; 


\section{Przhevalskiy N.M.}

1949 Путешествие в Уссурийскоммм крае. 1867-1869 гг. Владивосток [Travel in Sasaki, Shiro the Ussuri Krai. 1867-1869 Vladivostok];

2010 Voices of Hunters on Socialist Modernisation: From a Case Study of the Udehe in the Russian Far East. Inner Asia 12, pp. 177-197;

2011 Sacred places and masters of hunting luck in the forest worlds of the Udege people of the Russian Far East. In: Landscape and Culture in Northern Eurasia, edited by Peter Jordan, Taylor \& Francis Group. Routledge, New York, pp. 257279;

2016 A history of the Far East indigenous peoples transborder activities between the Russian and Chinese empires. Senry Ethnological Studies. Kyoto: National Museum of Ethnology, Vol. 92, pp. 161-193;

\section{Shestakov A.M.}

1891 ОписаниесъемкирекиБекина, произведеннойсотником А.М.Шестаковым. In: Из истории заселения Пожарского района: документы и материалы. Владивосток: Российский государственный исторический архив Дальнего Востока, 2010 [Description of the shooting of the Bekin River, made by the centurion A.Shestakov. In: From the history of settlement Pozharsky district: documents and materials. Vladivostok: Russian State Historical Archive of the Far East], pp. 25-44;

\section{Startsev, Anatoly F.}

1996 Материальная культура удэгейцев (вторая половина XIX-XX в.) Владивосток: ДВО РАН; [Material culture of Udehe (second part of XIX-XX c.), Vladivostok: FEB RAS] pp. 128-147;

2014 Внедрение сельского хозяйства в традиционную культуру аборигенов приамурья и приморья. Труды Института истории, археологии и этнографии народов Дальнего Востока ДВО РАН. Том ХVI. Владивосток, ИИАЭ ДВО РАН; [Introduction of agriculture in traditional culture of the natives of Priamurye and Primorye. In: Annals of the Institute of History, Archeology and Ethnography of the Peoples of the Far East, Far Eastern Branch of the Russian Academy of Sciences. Volume XVI. Vladivostok, IIAE FEB RAS], pp. 22-28.;

2017 Этнические представления тунгусо-маньчжуров о природе и обществе [Ethnic perceptions of the Tungus-Manchus about nature and society]. Владивосток: Дальнаука.;

\section{Venyukov M.I.}

1970 Путешествия по Приамурью, Китаю и Японии. Хабаровск. [Travels around Amur, China and Japan. Khabarovsk.]; 